\title{
Falling Fertility Rates: New Challenges to the Welfare State
}

\author{
Allison E. Vos \\ The University of North Carolina at Chapel Hill \\ Department of Political Science \\ avos@unc.edu
}

For delivery at the $11^{\text {th }}$ Biennial EUSA conference, Los Angeles, April 23-25, 2009 


\begin{abstract}
One of the biggest issues currently plaguing many advanced industrialized countries is the persistence of low fertility rates. Decreasing fertility rates threaten economic growth, while government budgets have to accommodate more pension and health services as the number of adults of working age who contribute to older generations' pensions diminishes. I examine the determinants of fertility levels at the national level of seventeen OECD countries. Specifically, I perform a pooled time series analysis covering the time period 1990-1999. The analysis yields evidence that the types of state policies - active labor market programs, family-friendly policies, and employment protection laws_-play a significant role in either helping or hindering fertility levels. I find that Active Labor Market Policies and generous work and family policies encourage higher fertility rates, while the presence of Employment Protection Legislation_rules concerning hiring and firing - hinders the growth of fertility rates.
\end{abstract}




\section{Table of Contents}

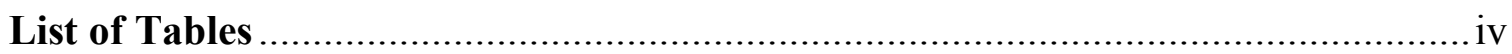

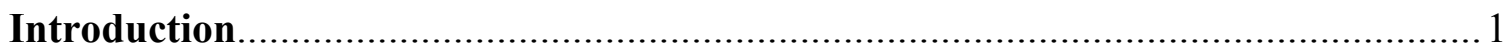

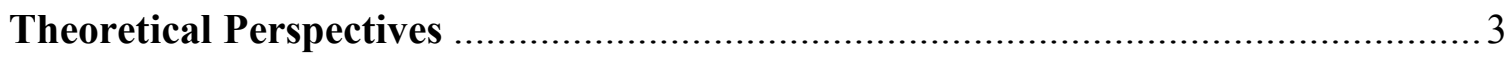

Gendering the welfare state dimension ...............................................................

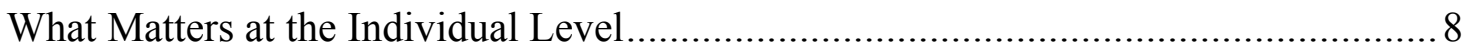

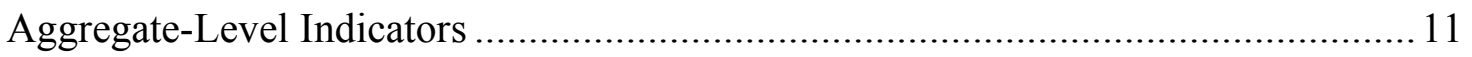

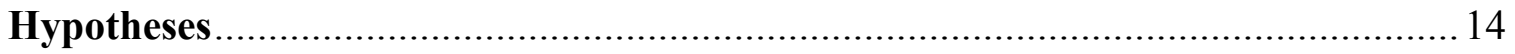

Active Labor Market Policies ............................................................................. 14

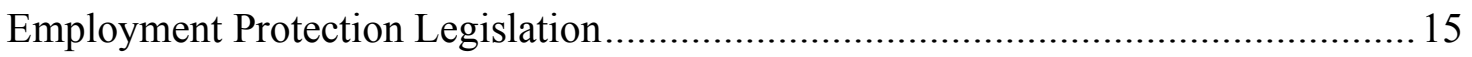

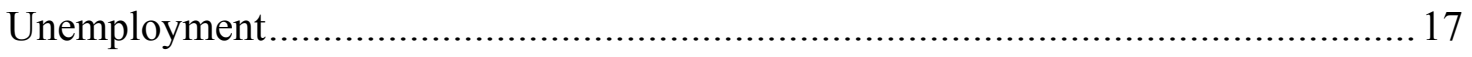

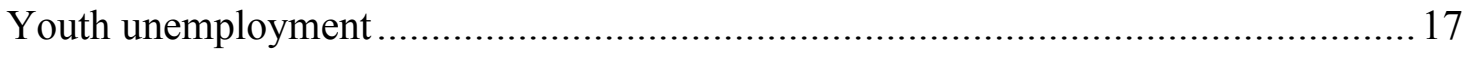

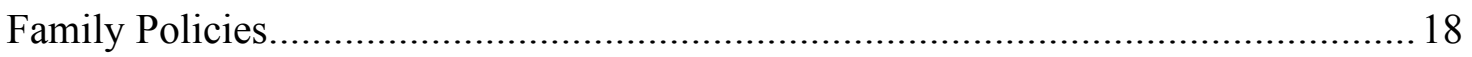

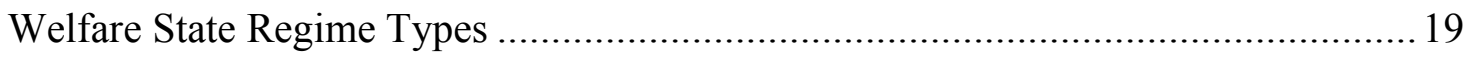

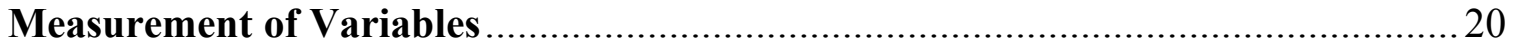

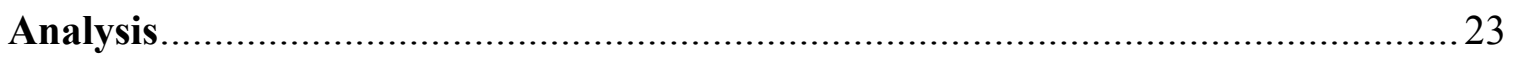

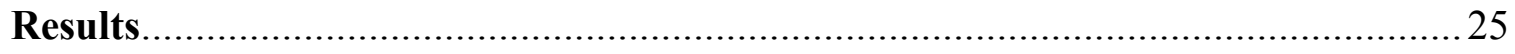

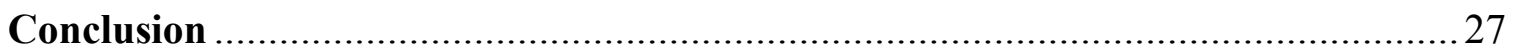

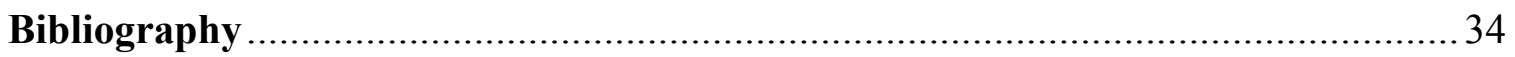




\section{List of Tables}

Table 1. Variable Descriptions and Hypothesized Effects on Fertility Level............31

Table 2. Mean Values of Variables by Country................................... 32

Table 3. Prais-Winsten Models of Determinants of Fertility Levels....................33

Table 4. Prais-Winsten Model of Fertility Level by Social Welfare Regime Type...33 


\section{Introduction}

One of the biggest issues currently plaguing many advanced industrial countries is the persistence of low fertility rates. In the European Union (EU), all Member States but Ireland have a fertility rate below 2.1 , the rate necessary to replace the current population (Jenson, 2006). In 2001, the fertility rate of the EU 25 (including the additional ten member states that would join the EU in 2004) was 1.46, while the range in the EU 15 (the fifteen member countries prior to enlargement in 2004) was from 1.89 (Ireland and France) to 1.22 (Spain; Jenson, 2006). Today's figures reflect only slight increases in some countries, with continued widespread systemically low fertility. The dilemma of low fertility stems from concern that the EU's future-its very quality of life-is menaced by a failure of the population to replace itself. Decreasing fertility rates threaten economic growth, while government budgets face the possibility of accommodating more pension and health services, as the number of adults of working age who contribute to older generations' pensions-let alone who can provide care and support for older people—diminishes.

For these reasons, I examine the determinants of fertility levels at the national level of seventeen OECD countries. Specifically, I perform a pooled time series analysis using country-years as the unit of analysis, covering the time period 1990-1999. The analysis yields evidence that the types of state policies - active labor market programs, 
family-friendly policies, and employment protection laws-play a significant role in either helping or hindering fertility levels. I find that Active Labor Market Policies and generous work and family policies encourage higher fertility rates, while the presence of Employment Protection Legislation—-largely, rules concerning hiring and firing-hinders the growth of fertility rates. The paper presents compelling evidence for differentiating between types of policies that either help or hinder population growth in advanced industrialized countries.

In addressing the issue of low fertility in Europe, we are inevitably confronted with a combination of institutional and human factors: while governments can attempt to put into place institutions and policies that will encourage childbirth (such as subsidies for children, family leave policies, and day care facilities), population reproduction is fundamentally a micro-level decision. The bottom line is that women and men must choose to have children; no number of institutional configurations will by themselves result in the birth of babies. Rather, it is the combination of systems of welfare provision, people's ability to provide for their wellbeing, and the choice of women and men to conceive children, that will likely result in increased fertility rates across Europe. 


\section{Theoretical Perspectives}

We are confronted with the question of just what encourages a rise in fertility levels, and why we have seen a drop in birthrates in the first place. Until the women's movement gained momentum in the 1970s, the dominant institutional family form in advanced industrial countries was the 'male breadwinner model', in which the man maintains outside employment while the woman's domain was in the home, caring for children and performing household tasks like cleaning, cooking, and the like. This family model was premised on the notion that there was a natural societal differentiation between men and women that required the man to be the provider and protector, and the woman to be the caregiver and reproducer. The male breadwinner model dominated the high fertility period of the baby-boom era, in which women's roles were relegated primarily to rearing children and maintaining the home. Given little alternative, it is not difficult to see why women would bear multiple children: this was their 'job'.

In the current era, different societal institutions have distanced themselves successfully from the male breadwinner model and have moved in the direction of increased gender equity. Of course, some of the changes witnessed in post-1970s Europe stemmed not solely from a noble quest for gender egalitarianism, but also from the fact that, for many people-women and men alike-employment became an economic necessity, rather than purely a matter of desire. New social pressures emerged as unions 
lost power, family wages dwindled, living standards stagnated, and family forms confronted instability, leading people to adapt to the changing constraints of the day.

In today's world, especially in the realms of education and employment, the male breadwinner model is largely defunct: in most advanced industrial countries, women receive higher education in equal, if not greater, percentages than men, and through initiatives like equal employment opportunity legislation, women suffer less discrimination in employment selection today than in previous eras (McDonald, 2000). No longer limited to strict roles of 'housewife' or 'breadwinner', women and men alike embody more diversity in their joint roles in the family and workplace. However, with increased gender equity comes the challenge of balancing work and family life - a challenge which, as one hypothesis goes, may limit women's real choices between children and employment, leading to low fertility (Esping-Andersen, 2002; McDonald, 2000). In other words, women may have gained 'false' gender equity in that while they may occupy more equitable roles with men in the public sphere, in the private sphere-i.e. life at homethey are faced with family roles that continue to constrain their choices.

Furthermore, the structure of the family has changed over the decades. By the 1990s across Europe, marriage rates were low and/or declining, the mean age at first marriage and at first birth increased, and fertility dropped below the replacement rate of 2.1 (Council of Europe, 2002). Demographers distinguish between three levels of belowreplacement fertility: 1) low fertility: at least 1.5 children per woman; 2) very low fertility: between 1.3 and 1.5 children per woman; and 3) lowest low fertility: fewer than 1.3 children per woman (Billari and Kohler, 2004; Kohler et al., 2002). We witness varying 
low levels of fertility across Europe, ranging from southern, central, and eastern Europe and Germany at the lowest end of the fertility spectrum, to the medium-range (e.g. Belgium, the Netherlands, Switzerland), to highest fertility levels (e.g. the Nordic countries, France, Ireland, the UK).

Examining fertility rates has yielded some clarification on the relationship between levels of religiosity and fertility, and women's labor force participation and fertility. Countries with higher levels of religiosity and traditional (Catholic) family values, e.g. Spain and Italy, are in fact among the lowest fertility group (Billari, 2004). Moreover, the cross-country relationship between female participation rates and fertility rates has reversed its sign; the correlation between total fertility rates (TFR) and female participation rates (FPR) across developed countries was negative and strongly significant during the 1970s up to the early 1980s (Ahn and Mira, 2002). However, beginning in the mid- to late 1980s, the correlation became positive and equally significant. That is, as more women became gainfully employed, levels of fertility declined less. Several scholars (Ahn and Mira, 2002; Hotz et al., 1997; Rindfuss and Brewster, 1996) have posited a weakening link between female employment and fertility due to increased use of market childcare and the rising income effect of wages at high levels of the female wage.

Gendering the welfare state dimension

Although gender and the family were dimensions that were conspicuously absent from earlier welfare policy regime analyses of the 1980s (Orloff, 1993), current theorizing 
about the welfare state recognizes the significance of relationships between states, markets, and families, and the impact of these on society (Gornick and Meyers, 2003; Korpi, 2000; Esping-Andersen, 1999). Furthermore, analyses focusing on the ability of women to combine parenting and paid work have sought to evaluate how different welfare states either enhance or limit women's opportunities in this regard (Gornick and Meyers, 2003; Gornick et al., 1997).

Gender equity and the reversal in the 1980s of the negative relationship between female labor force participation and fertility levels - at the national level-became a source of great interest in the academic world (Rindfuss et al., 2003; Ahn and Mira, 2002; Brewster and Rindfuss, 2000). According to McDonald (2000), the transition from higher fertility (above 2.1) to fertility merely at the replacement level follows from greater equality shared between men and women in families. Gender equity promotes lower fertility by increasing the likelihood that women will have more alternatives to childrearing, thus securing for themselves alternative avenues to success, satisfaction, and position in society.

Put another way, evolution of gender roles has increased the opportunity costs of mothers' choices to refrain from entering the labor market: this is a point on which social demographers and economists agree, and for which substantial empirical evidence exists (Morgan and Taylor, 2006). However, as gender equity rises in individual-oriented institutions (i.e. education, the economy, politics), it may still remain low within the family or in policies aimed at impacting families (i.e. parental leave policies). As a result, fertility can fall to very low levels, especially among societies that are characterized as 
being more patriarchal than others, i.e. Japan, Italy, Spain, while remaining closer to replacement levels in more gender-egalitarian societies, i.e. Scandinavia and the U.S. (Rindfuss et al., 2003; Gauthier and Hatzius, 1997).

Rindfuss et al. (2003) find that the relationship between fertility rates and female labor force participation varies across countries, with those countries that minimize the incompatibility between mother and work roles-i.e. facilitate the efforts of women who want to fill both roles-being more likely to see increasing numbers of working mothers. Countries in this group are likely to have higher proportions of females who are both employed and mothers, because women can more easily combine these two roles, than countries that do little to minimize the role incompatibility. As Esping-Andersen (1990, 1999) and others have pointed out, the institutions and policies of the three 'worlds' of welfare states vary markedly, with the Nordic countries most able to offer women the opportunity to combine work, both part-time and full-time, and motherhood, followed in various rankings by 'Continental European' and Anglo-Saxon countries, with Southern European countries representing some of the lowest fertility rates.

Esping-Andersen (1999) identifies the employment/parenting relationship as embodying a certain 'risk', which stands for the degree to which a person is dependent on the family or a job for his or her welfare. Where the state absorbs risks-i.e. provides unemployment insurance and/or benefits, or subsidizes childcare- the attainment of people's needs is both 'de-commodified' (removed from the market) and 'de-familialized' (removed from the family). Similarly, the label 'familialistic' denotes a designation of a maximum of welfare obligations to the household; in the same vein, the term 'de- 
familialization' represents policies that lessen individuals' reliance on the family.

Contemporary postindustrial society is characterized not by the stable one-earner family that was once considered typical, but rather by an increase in cohabitation and single-person households, dual-earner families, single parenthood, separation and divorce, and decreasing fertility. De-familialization for women is generally a precondition for their capacity to enter the labor market (Orloff, 1993). The burden on women of household maintenance and caring for children and/or elders needs to be lessened in order for them to be able to enter the marketplace and maintain employment. The most familialistic regimes, such as Italy and Spain, have the least developed family policies; familialism encourages a passive family policy due mostly to the influence of Catholic social teachings and the principle of subsidiarity - that is, limiting public interference to situations where primary social networks (i.e. the family) fail (Esping-Andersen, 1999). These structural aspectsalong with norms and conceptions of women's and men's roles and identities—constrain and channel behavior, and are presumed to affect national fertility levels. 'Structural aspects' include family structure, childcare provision, consumer markets, government policies, fiscal incentives, etc. (Morgan and Taylor, 2006).

\section{What Matters at the Individual Level}

We know that the relationship between female labor force participation and fertility is negative at the individual level, due to the fact that women who are employed have fewer children, on average, than women who are not, and that women with children 
spend less time in paid employment, on average, than women without children (Brewster and Rindfuss 2000). Thus we are presented with the important question of how a negative relationship between fertility and employment at the individual level can be translated into a positive relationship at the aggregate level.

Studies have shown that women's work patterns are strongly tied to changes in their family status, with most employed women leaving paid work for some time following a birth (Brewster and Rindfuss 2000). The duration of this leave from work varies among women and across countries, depending on leave policies, fiscal incentives, and childcare availability. In Japan and Ireland, for example, where cultural practices prescribe intensive maternal involvement in children's care, new mothers typically leave the workforce for prolonged periods, averaging a decade or more (Brewster and Rindfuss 2000). Women in Germany likewise tend to exit the labor force for extended periods following a birth, due to fiscal incentives to do so, a pronounced shortage of childcare, and school-day schedules that vary by the age of the child and often do not conform to workday schedules (Brewster and Rindfuss 2000). However, in the United States and the Nordic countries, the labor force participation rates of new mothers and mothers with preschool-age children are relatively high, although most women in these countries take some amount of leave (Brewster and Rindfuss 2000). The Nordic countries provide an example of the most progressive leaves: employers must offer paid leave to new mothers and new fathers, with leave lasting from four months to approximately one year (Ellingsaeter and Rønsen 1996, Bernhardt 1986 in Brewster and Rindfuss 2000). Maternal leaves in the United States average about twenty weeks and are usually unpaid; 
moreover, the rate of return is rapid, with $40 \%$ of women returning to work within three months and 86\% returning within a year (Desai and Waite 1991).

On an individual level, the potential incompatibility of work and motherhood may be a function of existing gender norms in society and power relations - or roles—within marriage or couplehood. Countries in which traditional gender patterns have changed to allow more equality between the sexes are more likely to have organized childcare facilities and other provisions that facilitate the combination of employment and parenthood (Bernhardt 1993). Modification of gender roles can also be seen in the tendency for men to figure more actively in parenting, not simply in economic terms, but in devoting more time to the care of the child, thus allowing both parents to have a more equal share of time to devote to both work and childcare. The expectation is that the more egalitarian men's and women's roles in the household and raising children, the greater the likelihood of more children (or at least, the possibility to have children).

One mechanism for transforming the negative relationship between fertility and women's employment into a positive one focuses on the role of institutions in mediating what can be seen as the "incompatibility factor" between paid work and motherhood. Rindfuss and Brewster (1996) suggest that "the negative association between fertility and labor force participation can be expected to diminish as the conflict between work and family responsibilities is reduced — whether by a change in the nature of work life, shifts in the social organization of childcare, or a combination of the two" (p. 262). This argument is in line with Esping-Andersen (1999) and others who highlight the role of institutions in mitigating the role incompatibility of parenting and participation in the 
labor force.

\section{Aggregate-Level Indicators}

One mitigating mechanism exhibited by the state is family policy, designed to regulate social and economic relations within families as well as between families and other social institutions (Wennemo 1993; Brewster and Rindfuss 2000). The term "family policy" encompasses myriad debatable goals ranging from ensuring equitable living standards to actively encouraging larger family sizes. And while all advanced industrial nations allow some form of provision for working families, states' positions on families and family policies differ markedly (Brewster and Rindfuss 2000). Similarly to Esping-Andersen's (1990) clustering of welfare-state regimes into three "worlds," Chesnais (1996) proposes a conceptual mechanism for distinguishing between familyoriented state policies across Europe. He defines "nations of families" as including those in which the extended family is at the center of key life decisions (i.e. marriage and childbearing) and in which family networks are usually responsible for providing family services. In contrast, "nations of individuals" embody a strong notion of individualism and social equality. In the "nations of families," policies either support the "male breadwinner" model, as in Germany where the protection of the family as a key pillar of society is formally upheld in the 1949 Basic Law, or they simply do not intervene in the family realm, as in Italy (Chesnais 1996). "Nations of individuals" like the United Kingdom and Sweden, on the other hand, tend to have policies that more actively 
promote women's equality and acknowledge diverse family forms.

Childcare arrangements are another factor that influence women's ability to reconcile family duties and participation in the labor force. According to Rindfuss and Brewster (1996), norms and attitudes about childcare directly relate to the concept of role incompatibility. The incompatibility between women's roles as mothers and employees varies depending on beliefs about appropriate caregivers and about the ages at which children require close supervision. The higher degree of maternal supervision that norms prescribe, argue the authors, the greater the role incompatibility and, therefore, the stronger the negative relationship between fertility and women's labor force participation.

The availability of childcare also figures in the picture, as does its cost. In most European countries, childcare is at least partly publicly funded for children age three and older (Brewster and Rindfuss 2000). For example, in Sweden and Finland, the state subsidizes childcare and parents pay a nominal fee, depending on income, for childcare in state-licensed centers or family daycare homes (Mikkola 1991; Sundstrom 1991). France has a combination of private and public childcare providers, all of which receive some state subsidies, with the percentage of the cost that parents pay varying from $28 \%$ to 90\% depending on provider type (David and Starzec 1991). In the English-speaking countries, by contrast, most childcare is not subsidized, leaving people to pay market costs and rely on private means for childcare provision.

The underlying assumption of role incompatibility between labor force participation and childrearing is that women will adjust either one to accommodate for the other. In fact, however, the evidence suggests that women adjust both factors, and that 
the degree to which they do this varies across countries (Brewster and Rindfuss 2000). Because labor force participation and fertility are more accurately conceived as processes that develop over time rather than as static events, we must conceptualize the fertilityemployment relationship as a dynamic model (Bernhardt 1993; Brewster and Rindfuss 2000). That is, individuals may enter, exit, and re-enter the workforce at any point, just as fertility decisions, both the number and timing of births, are also fluid over time as circumstances change. 


\title{
Hypotheses
}

\author{
Active Labor Market Policies
}

Table 1 shows descriptions of the variables in the analysis and their hypothesized effects on fertility level. Active Labor Market Policies (ALMP) retrain and reintegrate unemployed workers into the labor force. The use of active labor market programs is often motivated by the need to upgrade the skills of long-term unemployed in order to improve their employability. These policies, which constitute an active approach to putting people back into the workforce, should have positive impact on employment (and thus income) by increasing the employability of the working-age population. Furthermore, ALMP help absorb unemployed youth in either education or sponsored employment. The labor market policies play a vital role in lessening the consequences of youth unemployment in Nordic countries: in these countries, 2-2.5 percent of the youth labor force is in active labor market programs, compared to a Continental European average of 1.2 percent. Similarly, more than 6 percent of the Scandinavian labor force is in labor market training schemes, compared to 2.3 percent in Continental Europe (EspingAndersen 1999). Thus I hypothesize that greater spending on ALMP will yield an increase in fertility through creating a more secure and prosperous financial outlook for both men and women and easing their reintegration into the workforce. ALMP are 
especially critical in reintegrating youth into the workforce, thereby reducing the detrimental effect of delayed family formation due to young people remaining longer with their parents (Esping-Andersen 1999).

\section{Employment Protection Legislation}

Some form of employment protection legislation (EPL) can be found in nearly every OECD country, although significant cross-national differences exist in the breadth and strictness of these measures (see OECD 1999), and the overall effects produced by these policies remain disputed. EPL refers in general to regulations about hiring (e.g. rules favoring disadvantaged groups, conditions for using temporary or fixed-term contracts, training requirements) and firing (e.g. redundancy procedures, mandated notification periods and severance payments, special requirements for collective dismissals and shorttime work schemes). In countries with strict job protection laws and various restrictions on temporary and part-time work, a dual labor market emerges in which "outsiders" (those without stable employment) face difficulty in obtaining the secure positions enjoyed by "insiders." The high-EPL model of privileging the core workforce yields this insider/outsider divide: the high wages and job security enjoyed by chiefly male insiders is predicated in effect on the exclusion of youth and women (Esping-Andersen 1999).

While there have not been many studies on the effect of employment protection policies on fertility, it is generally agreed that stricter employment protection laws inhibit employment among youth and outsiders who are left out of protected labor schemes, and 
propagate the insider/outsider divide (Rueda, 2005). The implications of this insider/outsider divide for fertility stem from the fact that in countries with high levels of employment protection rigidities, young people live longer with their parents, and as a result, are likely to delay childbirth and other life developments (Fogli, 2004).

Furthermore, flexible labor legislation and widely available part-time employment aid the dual role of parent and worker. Rigid labor regulations that favor the full-time male employee in European countries - most notably in Southern Europe- hinder parttime employment (Adsera, 2005). As more women enter the workforce, labor market institutions need to be adapted to accommodate flexibility in employment arrangements, in order to ease the combination of employment and motherhood. Rigid labor market institutions designed to protect mature male workers have produced higher female unemployment rates, in addition to lower fertility (ibid.). Bertola et al. (2002) have shown that in countries with high levels of employment protection, increased activity in temporary and informal employment has hampered women's long-term labor force involvement, and thus hinders long-term family planning.

Therefore, higher levels of EPL result in delayed family formation, as young people live for a longer period of time with their parents while waiting to secure employment and women are prone to labor market exclusion. This expectation is best captured when evaluated through the insider/outsider lens: the higher the EPL, and thus the ratio of outsiders to insiders in the labor force, the lower will be the fertility level, since especially youth and women under these conditions have difficulty finding secure jobs. As a result, people have fewer children than they would like to (Jenson 2006; Chesnais 1996). EPL discourages women from having children because it results in an 
"either/or" situation: where conditions are unfavorable for combining work and parenthood, women will choose either one or the other. I hypothesize that the stronger the presence of EPL in a country, the lower the fertility level.

\section{Unemployment}

The higher the level of unemployment, the more people's financial outlooks are not stable. Thus, my hypothesis is that greater unemployment will result in lower fertility as people are faced with insecure financial prospects and cannot provide financially for their families.

Youth unemployment

The percentage of unemployed youth is another expression of the insider/outsider divide. A low-fertility equilibrium may concretize when combined with factors that hinder family formation, one of which is youth unemployment (Esping-Andersen 1999). The problem arises when youth do not have alternative means of income and therefore delay family formation while they are seeking employment. In familialistic welfare regimes, economic support for children is a family obligation. In Southern Europe, young adults continue to live with their parents until and even beyond age 30; estimates from the 1994 Europanel show that the proportion of 20-30-year-old unemployed Italian youth living with parents is 81 percent (Esping-Andersen 1999). Thus we have reason to 
hypothesize that high youth unemployment will be negatively correlated with fertility levels, as young people delay family formation due to their exclusion from the labor market.

\section{Family Policies}

The ability of women and men to combine paid work and parenthood rests arguably on the degree to which measures exist to ease the financial burden of raising a family and ease time constraints of raising children while attempting to maintain employment. Where social and economic institutions have adapted more rapidly to the gender equity model (away from the emphasis on the male breadwinner model), as in the Nordic countries and in France, fertility has not fallen to dire, low levels. Conversely, in countries where attitudes toward the family have mirrored the male breadwinner perspective - that is, where employment for mothers faces restrictions due to lack of family support services (i.e. childcare) and where societal arrangements increase the difficulty of combining work and parenthood (i.e. parental leave conditions), fertility rates have plummeted (McDonald 2000). Thus, we hypothesize a positive relationship between both government spending on daycare services and fertility levels, and between parental leave duration/benefits and fertility levels. 
Welfare State Regime Types

Table 2 shows the mean values of the key indicators and dependent variable, broken down by country and welfare regime type. Empirically, we observe two different paths to higher fertility: the Liberal welfare state path and the Social Democratic one. The Nordic countries have generous work/family policies and ALMP and moderate EPL levels. Conversely, the Liberal path has weak family policies, ALMP, and EPL. We see from Table 2 that the values of the independent variables accounting for higher or lower fertility vary by regime type. Thus, these data show the relationship between welfare regime type and fertility level, which we can then compare with what we learn about specific independent variables from our analysis. 


\section{Measurement of Variables}

The analysis covers the period 1990-1999 for 17 advanced industrial countries. The main data sources are the Organization for Economic Cooperation and Development (OECD) and Gauthier and Bortnik's (2001) Comparative Maternity, Parental, and Childcare database. The dependent variable in the analysis is the fertility rate, or total births per woman, taken from the World Bank.

Data on employment protection legislation (EPL) are the OECD's (2004) recently released annual time series. The summary index summarizes a number of subindices measuring the difficulty of layoff (notice, severance pay, etc.) and regulations restricting the use of temporary work (Bradley and Stephens 2007). This index is calculated along 18 basic items, which can be classified in three main areas: 1) employment protection of regular workers against individual dismissal; 2) specific requirements for collective dismissals; and 3) regulation of temporary forms of employment. Active Labor Market Policy (ALMP) effort is operationalized as active labor market spending as a percentage of GDP divided by the unemployed portion of the population.

The variables measuring parental leave and benefits come from Gauthier and Bortnik's (2001) dataset. The summary variable that I use to capture parental leave generosity is the average replacement rate for 52 weeks, which is calculated from maternity/parental leave duration (in weeks) and maternity/parental leave benefits 
(expressed as a percentage of women's wages in manufacturing). Where the leave period was more than one year, as in Finland in 1991-1992 and in Sweden 1990-1999 (54 and 64 weeks, respectively), the replacement rate was recalibrated to fit a scale of 52 weeks. The variable measuring daycare spending as a percentage of GDP is drawn from both the OECD and Jaumotte series on daycare spending. Based on Gornick and Meyers, Chapter 7, I use Jaumotte for Belgium and and Norway because OECD appears to be too low, as well as for Canada, for which OECD had no data. For the UK and France, I use OECD and fill in missing data from Jaumotte. For the U.S., Jaumotte is used with reservations. Based on Gornick and Meyers, Jaumotte appears to be too high but OECD appears to be much too low. Finally, I use a composite variable capturing work and family policy generosity, which is a combination of the standardized maternity/parental generosity variable and the standardized daycare spending variable. I use this composite variable because we cannot put both parental leave and daycare variables into the regressions at the same time, due to the problem of multicollinearity (correlation $=.89$ ). Therefore, I have three separate models using daycare spending, parental leave, and the composite work and family policy variables, respectively.

The youth unemployment variable is the rate of total youth unemployment, age 1524, taken from the World Development Indicators (World Bank). Overall unemployment rate is taken from OECD. Under the theoretical premise that a given year's fertility rate is not a function of the effect of the economic cycle of that same year, but rather reflects cumulative economic effects, I take the average of the previous five years of economic indicators: unemployment rate (both total and youth) and employment protection 
legislation. My argument is that the broader economic picture-whether favorable or disadvantageous - influences people's decisions to have a child or not. When unemployment is high, people's economic outlooks are shaky, thus reflecting an unstable financial environment in which to have children. Moreover, as EPL policies have been in effect over several years, the insider/outsider dimensions of the labor market become entrenched; if a person has been on the "outside" economically for the past several years, he/she will be less inclined to perceive him-/herself in a position to raise a child and will be in a situation of delayed family formation. 


\section{Analysis}

I conduct a pooled time series analysis of the determinants of the fertility rate, the dependent variable, using panel-corrected standard errors and Prais Winsten regression estimation, corrections for first-order auto-regressiveness, and imposition of a common rho for all cross-sections across seventeen OECD countries from 1990-1999, with country-years as my unit of analysis. Hicks (1994) notes that "errors for regression equations estimated from pooled data using OLS [ordinary least squares regression] procedures tend to be (1) temporally autoregressive, (2) cross-sectionally heteroskedastic, and (3) cross-sectionally correlated as well as (4) conceal unit and period effects and (5) reflect some causal heterogeneity across space, time, or both" (p.172). Beck and Katz (2004:16-17) have shown that correcting for first order auto-regressiveness actually does include a lagged dependent variable on the right hand side of the equation (known as Prais Winsten estimations). Thus, it deals with the problem of serial correlation that is found in pooled time series, but without suppressing the power of other independent variables. The analysis is implemented using version 9.1 of the STATA econometrics program.

Beck and Katz (1996) and others have argued for the inclusion of country dummies in order to deal with omitted variable bias. Plümper et al. (2005: 330-34) in their recent treatment of this issue have countered that inclusion of country dummies does much more than eliminate omitted variable bias. It also (1) eliminates any variation in the 
dependent variable which is due to time invariant factors such as difference in constitutional structures, (2) greatly reduces the coefficients of factors that vary mainly between countries, (3) eliminates any differences in the dependent variable due to differences at time $t$ in the time series, and (4) completely absorb(s) differences in the level of the independent variables across the units (p.331, emphasis in the original). Elaborating on this last point, they argue that if one hypothesizes that the level of the independent variable has an effect on the level of the dependent variables (e.g. the level of unemployment on the level of fertility) a fixed effects specification is not the appropriate model. If a theory predicts level effects, one should not include unit dummies. In these cases, allowing for a mild bias resulting from omitted variables is less harmful than running a fixed effects specification (p. 334). I hypothesize effects in the levels of the independent variables prior to time $t$ on the level of the dependent variable at time $t$, and effects of levels of the independent variables on levels of the dependent variable. In addition, variation in several of the independent variables, including the critical policy variables, is primarily cross-sectional. Thus, it is clear that fixed effects estimation or the inclusion of country dummies is not appropriate in this case (cf. Huo, Nelson, Stephens 2008). 


\section{Results}

Table 3 shows the results of the analyses, and Table 4 shows the overall effects of welfare regime type on fertility level. As hypothesized, EPL has an inverse relationship with fertility levels: the higher the EPL, the lower the fertility. This result corresponds to the expectation that as the number of outsiders to insiders increases, due to protection of the insiders' jobs and exclusion of certain groups (women and youth in particular) from the labor market, fertility levels will drop, due to people's concerns about their financial well-being and ensuing delayed family formation. In all the models, EPL remains the most significant variable and also has the strongest effect. When we move two standard deviations on the measure of EPL, we get the biggest change in fertility rate: a decrease of .22. The implications of this effect are substantial: if employment protection legislation remains as is, there will be no change in fertility level. Only when legislation is modified to diminish the effects of the insider/outsider divide would we expect to see a positive change in the effect of EPL on people's decisions to have children.

The variable with the second-largest effect is the composite "work and family policy" variable, reflecting the positive correlation between maternal/parental leave policies and government daycare spending, and having children. Moving two standard deviations yields a .15 increase in fertility rate; isolating the composite variable's two 
components, leave generosity and daycare spending, yields an increase of .11 in fertility rate for each. Thus we witness the hypothesized correlation with fertility level: the more parental benefits and childcare spending, the greater the fertility levels.

Consistent with our hypothesis, ALMP have the opposite effect of EPL, providing support for the idea that policies promoting active engagement in the workforce and retraining of the unemployed will strengthen overall employment (and therefore people's financial outlooks), create more opportunity for dual-earner families, and lead to higher fertility. The size of the effect of ALMP is significant: moving two standard deviations yields an increase in fertility rate of .08 .

Perhaps surprisingly, overall unemployment is not significant in any model. However, the unemployment variable captures average unemployment rates at any given point in time, and does not reflect the fact that different individuals will cycle in and out of employment at various points in their lives, and thus the degree to which their financial outlooks are bleak will vary. In other words, the unemployment variable does not show cyclical effects on fertility. France, Germany, Belgium, and other continental European countries have consistently high levels of unemployment, whereas the Nordic countries do not, but nonetheless, we cannot conclude that unemployment does not have some bearing on people's choices to have children.

Table 4 regresses fertility on the welfare state regime dummy variables. The overall variation is not significantly different from the models with theoretically meaningful independent variables in Table 3. This indicates that the variables in Table 3 do, in fact, explain why the welfare state regimes differ in their fertility levels. 


\section{Conclusion}

To summarize, this analysis offers support for the hypothesis that government policies can and do affect people's choices to have children. Active Labor Market Policies encourage retraining and reintegrating unemployed workers into the labor force, which in turn place more potential and actual mothers and fathers into jobs, earning income, and securing the financial means to raise children. Welfare regimes that enact active labor market policies to encourage employment are expected to produce higher fertility levels, since the potential for dual-earner families rises, thus providing more money for financing childrearing. For example, despite roughly similar levels of aggregate unemployment and similarly compressed wage structures in Continental Europe and the Nordic countries, youth fare considerably better in the latter, due in large part to the Nordic welfare system of emphasis on active labor market programs (Esping-Andersen 1999).

Furthermore, as the Nordic countries embody a more gender-egalitarian social system and Liberal countries witness high percentages of female employment participation rates as compared with Continental countries, we witness an increase in fertility rate. Active de-familialization of welfare burdens in the social democratic welfare states, a passive or targeted-assistance approach in the liberal regimes, and a system of sustained familialism in Continental Europe (especially in southern Europe) embody the 
differences in the profile and intensity of social risks within families (Esping-Andersen 1999).

Additionally, employment protection policies have a contradictory effect on some people's financial well-being and choices to have children, and are correlated with lower fertility rates. The longer young people remain unemployed and live with their parentsan important dimension of the insider/outsider distinction - the longer they will wait to get married or begin independent lives, thus leading to a slowdown in fertility rates stemming from delayed family formation. The negative correlation between EPL and fertility rate reinforces the hypothesis that the insider/outsider dimension within the labor market-those who have secure jobs, and those who do not-affects whether or not people have children. For those who consider themselves to be financially secure, having children seems to be a viable option, but for those who are left out of the labor market and find it difficult to attain reliable employment, financial futures look bleak, and thus potentially affect the choice to have children.

In another study (Nelson and Stephens 2008), ALMP, work/family policies, and EPL are shown as being important determinants of women's labor force participation, with similar positive and negative effects as they have on fertility. Since we see from the data that ALMP and work/family generosity yield an increase in both female employment and fertility, we have evidence that these policies bridge the work/parenthood divide. Policies that reduce the conflict between parenthood and employment will be likely to encourage higher fertility rates. Family policies appear from this paper's analysis to be crucial in promoting an environment that is conducive to bearing children, through 
ensuring that employment-leave and childcare options exist, should people decide to have children. Both government daycare spending and leave generosity were shown in this analysis to be positively and significantly correlated with an increase in fertility rate.

The results show that there is not one magic cure-all as a solution to the workfamily-fertility nexus. Rather, it is a combination of opportunities available to people to reconcile work and parenting, such as quality childcare, financial resources, and overall adequate standard of living. These opportunities function in addition to values-valuing having children, but also valuing promoting equality between women and men and the attainment of their respective life goals.

Future research will need to identify the specific factors that people consider when deciding to have children, one mechanism for which will be to employ survey questions to this effect. Furthermore, future research must consider the implications of policy design. Not all childcare is equally accessible, affordable or adequate; not all parental leaves, even if paid, provide the same level of support for parental labor market participation and access to quality jobs. Moreover, as family structures change and marriage has become less traditional - e.g. many people now marry more than once in their lifetime, not all unions are between men and women, women have children as single mothers, and men and women alike wait longer to both get married and have their first child — policies aimed at reducing the work/family incompatibility will need to take these changes into account.

The $21^{\text {st }}$ century promises a significant challenge if fertility levels remain at perilously low levels. While increasing numbers of immigrants to OECD countries will ameliorate the problem of low fertility slightly because they will work and contribute to 
the pension system, as well as aid in increasing the population by having children, immigration remains a politically contested subject. Immigration can be viewed as one alternative - a complement to the problem of low fertility - but cannot be relied upon as the solution, for political and cultural reasons. States must confront the challenge of low fertility while acknowledging modern family models and equality of opportunity, rather than looking backward to archaic family and demographic models of yesteryear. 
Table 1: Variable Descriptions and Hypothesized Effects on Fertility Level

\begin{tabular}{lll}
\hline \hline Variable & $\begin{array}{l}\text { Description } \\
\text { Spending on active labor market policy } \\
\text { measures divided by the unemployed }\end{array}$ & Hypothesized Effect \\
Active Labor Market Policies & $\begin{array}{l}\text { population } \\
\text { Percentage of working-age population }\end{array}$ & + \\
Unemployment Level & unemployed \\
Youth unemployment & Rate of youth unemployment, age 15-24 & - \\
Employment protection & Index of employment protection legislation & - \\
Daycare spending & Daycare spending as a percentage of GDP & + \\
& Maternity/parental leave duration (in weeks) & \\
Leave generosity & $\begin{array}{l}\text { and leave benefits (as \% of women's wages in } \\
\text { manufacturing) }\end{array}$ & + \\
pomposite work and family & Combination of daycare spending and leave & + \\
Social Democratic welfare & generosity & + \\
regimes & Nordic countries & + \\
Christian Democratic welfare & Christian Dem. \& Continental European & - \\
regimes & countries & + \\
Liberal welfare regimes & Liberal market economies & + \\
\hline
\end{tabular}


Table 2: Mean Values of Variables by Country

Fertility Active Labor Unemployment rate Market Policy

Youth

Unemployment
Employment

Protection

Legislation
Daycare Spending
Maternity/ Work/

Parental Family

Leave Policy

\begin{tabular}{|c|c|c|c|c|c|c|c|c|}
\hline \multicolumn{9}{|c|}{ Social Democratic Welfare States } \\
\hline Denmark & 1.74 & 0.22 & 7.65 & 12.97 & 2.12 & 1.85 & 53.69 & 3.89 \\
\hline Finland & 1.79 & 0.17 & 8.22 & 24.97 & 2.21 & 1.15 & 76.98 & 3.70 \\
\hline Norway & 1.87 & 0.20 & 4.10 & 13.64 & 2.86 & 1.40 & 71.92 & 3.93 \\
\hline Sweden & 1.84 & 0.56 & 4.54 & 15.71 & 3.08 & 1.73 & 92.43 & 5.21 \\
\hline Mean & 1.81 & 0.29 & 6.13 & 16.82 & 2.57 & 1.53 & 73.76 & 4.18 \\
\hline \multicolumn{9}{|c|}{ Continental (Christian Democratic) Welfare States } \\
\hline Austria & 1.42 & 0.09 & 3.62 & 5.51 & 2.20 & 0.48 & 30.77 & 0.24 \\
\hline Belgium & 1.58 & 0.15 & 9.33 & 21.62 & 3.14 & 0.56 & 22.16 & -0.07 \\
\hline France & 1.73 & 0.10 & 9.95 & 27.59 & 2.91 & 0.68 & 27.51 & 0.81 \\
\hline Germany & 1.31 & 0.18 & 6.70 & 10.03 & 3.13 & 0.34 & 26.92 & -0.10 \\
\hline Italy & 1.23 & 0.04 & 9.32 & 38.47 & 3.57 & 0.10 & 33.08 & -0.31 \\
\hline Netherlands & 1.58 & 0.21 & 7.08 & 13.76 & 2.70 & 0.40 & 28.46 & -0.03 \\
\hline Switzerland & 1.51 & 0.22 & 1.77 & 6.54 & 1.10 & 0.14 & 0.00 & -1.79 \\
\hline Mean & 1.48 & 0.14 & 6.82 & 17.65 & 2.68 & 0.39 & 24.13 & -0.18 \\
\hline \multicolumn{9}{|c|}{ Liberal Welfare States } \\
\hline Australia & 1.83 & 0.06 & 8.33 & 18.31 & 0.94 & 0.12 & 0.00 & -1.76 \\
\hline Canada & 1.65 & 0.06 & 9.72 & 17.69 & 0.80 & 0.33 & 16.53 & -0.70 \\
\hline Ireland & 1.95 & 0.11 & 14.39 & 25.65 & 0.90 & 0.08 & 18.85 & -0.96 \\
\hline $\begin{array}{l}\text { United } \\
\text { Kingdom }\end{array}$ & 1.76 & 0.07 & 9.46 & 16.95 & 0.60 & 0.13 & 15.58 & -1.11 \\
\hline United States & 2.05 & 0.04 & 6.68 & 14.75 & 0.20 & 0.34 & 0.00 & -1.38 \\
\hline Mean & 1.85 & 0.07 & 9.72 & 18.67 & 0.69 & 0.20 & 10.19 & -1.18 \\
\hline Japan & 1.45 & 0.09 & 2.61 & 6.25 & 2.11 & 0.22 & 16.15 & -0.87 \\
\hline
\end{tabular}


Table 3: Prais-Winsten Models of Determinants of Fertility Levels Independent Variables Model 1

Active Labor Market Policies

$0.261 *$
Model 2 Model 3

Unemployment

0.000297

$0.261 * *$

$(0.13)$

$(0.011)$

0.00106

$0.245^{*}$

$-0.000664$

(0.012)

Youth unemployment

(0.0043)

Employment protection

$-0.108 * * *$

$-0.00237$

(0.0045)

legislation

Daycare spending

(0.023)

$0.0946 * * *$

$-0.102 * * *$

$(0.14)$

$-0.0000427$

(0.012)

$-0.00158$

$(0.0044)$

$-0.109^{* * *}$

(0.032)

Maternity/parental leave duration and leave benefits

Composite "work and family

$$
\text { (0.029) }
$$

policy" variable

$$
0.00218^{* *}
$$

(0.0010)

\section{Constant}

$1.804 * * *$

(0.060)

$N$

150

0.93

.897

Common Rho

Panel-corrected standard errors in parentheses.

Table 4: Prais-Winsten Model of Fertility Level by Social Welfare Regime Type (Christian Democratic as baseline) Independent Variables

Model 1

\begin{tabular}{l} 
Social Democratic \\
Liberal \\
Constant \\
Common Rho \\
$R^{2}$ \\
$N$ \\
\hline$* * * p=.001$.
\end{tabular}

Social Democratic

Liberal

$.303 * * *$

$.403 * * *$

$1.497 * * *$

$* * p=.001$ 


\section{Bibliography}

Ahn, N., Mira, P. 2002. A note on the changing relationship between fertility and female employment rates in developed countries. Journal of Population Economics. 15: 667-682.

Beck, N., Katz, J. 1996. Nuisance versus Substance: Specifying and Estimating Time Series Cross Sectional Models. Political Analysis. 1:1-36.

Beck, N., Katz, J. 2004. Random Coefficient Models. Political Analysis.

Bernhardt, E. 1993. Fertility and employment. European Sociological Review. 9(1): $25-42$.

Billari, F.C., Kohler, H.P. 2004. Patterns of low and lowest low fertility in Europe. Population Studies. 58: 161-76.

Bradley, D.H., Stephens, J.D. 2007. Employment Performance in OECD Countries: A Test of Neoliberal and Institutionalist Hypotheses. Comparative Political Studies. 40(12): 1486-1510.

Brewster, K.L., Rindfuss, R.R. 2000. Fertility and women's employment in industrialized nations. Annual Review of Sociology. 26: 271-96.

Chesnais, J-C. 1996. Fertility, family, and social policy in contemporary Western Europe. Population and Development Review. 22(4): 729-39.

Corcoran, M, Duncan, G.J., Ponza, M. 1984. Work experience, job segregation, and wages. In Sex Segregation in the Workplace: Trends, Explanations, Remedies, ed. B. Reskin, pp. 171-91. Washington, D.C.: National Academy of Sciences.

Council of Europe. 2002. Recent demographic developments in Europe. Strasbourg, France: Council of Europe Press.

Crouch, C. 1998. Labor market regulations, social policy, and job creation. In J. Gual (ed.), Job Creation (pp. 130-164). Cheltenham, UK: Edward Elgar.

David, M., Starzec, C. 1991. France: A diversity of policy options. See Kamerman \& Kahn, pp. 81-113.

Desai, S., Waite, L.J. 1991. Women's employment during pregnancy and after the first 
birth: occupational characteristics and work commitment. American Sociological Review. 56(4): 551-66.

DiPrete, T.A. 2002. Life course risks, mobility regimes, and mobility consequences: A comparison of Sweden, Germany, and the United States. American Journal of Sociology. 108: 267-309.

DiPrete, T.A., McManus, P.A. 2000. Family change, employment transitions, and the welfare state household income dynamics in the United States and West Germany. American Sociological Review. 65: 343-370.

Esping-Andersen, G. 1990. The three worlds of welfare capitalism. Princeton: Princeton University Press.

Esping-Andersen, G. 1999. Social foundations of postindustrial economies. Oxford: Oxford University Press.

Esping-Andersen, G., Regini, M. 1999. Why Deregulate Labor Markets? Oxford: Oxford University Press.

European Values Study Group and World Values Survey Association. 2006. European and World Values Surveys Four-wave Integrated Data File, 1981-2004, v. 20060423.

Gangl, M. 2004. Welfare states and the scar effects of unemployment: A comparative analysis of the United States and West Germany. American Journal of Sociology. 109(6): 1319-1364.

Gauthier, A.H., Bortnik, A. 2001. Comparative Maternity, Parental, and Childcare Database, Version 2 (University of Calgary). On-line.

Gauthier, A.H., Hatzius, J. 1997. Family benefits and fertility: an econometric analysis. Population Studies. 51: 295-306.

Gornick, J.C., Meyers, M.K. 2003. Families that work: Policies for reconciling parenthood and employment. New York: Russell Sage Foundation.

Gornick, J.C., Meyers, M.K., Ross, K.E. 1997. Supporting the employment of mothers: Policy variation across fourteen welfare states. Journal of European Social Policy. 7(1): 45-70.

Hicks, A. 1994. "Introduction to Pooling." in Thomas Janowski and Alexander Hicks, eds. The Comparative Political Economy of the Welfare State. New York: 
Cambridge University Press.

Hotz, V.J., Klerman, J.A., Willis, R.J. 1997. The economics of fertility in developed countries. In: Rosenzweig, M.R., Stark, O., eds. Handbook of Population and Family Economics. pp. 275-347.

Huber, E., Stephens, J.D. 2001. Development and Crisis of the Welfare State. Chicago: The University of Chicago Press.

Huo, J., Nelson, M. and Stephens, J. D. 2008. Decommodification and activation in social democratic policy: Resolving the paradox. Journal of European Social Policy. 18: 5-20.

Iversen, T. 2005. Capitalism, Democracy, and Welfare. New York: Cambridge University Press.

Jaumotte, F. 2003. Female labour force participation: Past trends and main determinants in OECD countries. OECD Economics Department Working Papers No. 376.

Jenson, J. 2006. Family, work, and welfare: Present and future challenges. Paper prepared for the workshop, "Family, work, and welfare in past and present: A transatlantic workshop," 10-11 November, University of North Carolina at Chapel Hill.

Kamerman, S., Kahn, A., eds. 1991. Child Care, Parental Leave, and the Under-3 's. New York: Auburn House.

Kohler, H.P., Billari, F.C., Ortega, J.A. 2002. The emergence of lowest-low fertility in Europe during the 1990s. Population Development Review. 28: 641-80.

Korpi, W. 2000. Faces of inequality: Gender, class, and patterns of inequalities in different types of welfare states. Social Politics. 7(2): 127-91.

McDonald, P. 2000. Gender equity, social institutions and the future of fertility. Journal of Population Research. 17(1): 1-16.

Mikkola, M. 1991. Finland: Supporting parental choice. See Kamerman \& Kahn 1991, pp. $145-70$.

Morgan, S.P., Taylor, M.G. 2006. Low fertility at the turn of the twenty-first century. Annual Review of Sociology. 32:375-99.

Nelson, M., Stephens, J.D. "The determinants of women's employment in OECD countries." Paper prepared for delivery at the Research Workshop on "The Political Economy of the Service Transition," Institute for International 
Integration Studies, Trinity College, Dublin, Ireland, May 16-17, 2008.

Organization for Economic Cooperation and Development. 1994. The OECD Jobs Study. Paris.

Organization for Economic Cooperation and Development. 1999. Employment Outlook. Paris.

Organization for Economic Cooperation and Development. 2004. Employment protection regulation and labour market performance. In OECD Employment Outlook (pp. 61-126).

Orloff, A.S. 1993. Gender and the social rights of citizenship: The comparative analysis of gender relations and welfare states. American Sociological Review. 58: 303-28.

Plümper, T., Troeger, V., Manow, P. 2005. Panel data analysis in comparative politics: linking method to theory. European Journal of Political Research 44(2): 327-35.

Rindfuss, R.R., Brewster, K.L. 1996. Childrearing and fertility. Population Development Review. 22(Supplement): 258-89.

Rindfuss, R.R., Guzzo, K.B., Morgan, S.P. 2003. The changing institutional context of low fertility. Population Research and Policy Review. 22: 411-38.

Scharpf, F.W. 2000. Economic changes, vulnerabilities, and institutional capabilities. In F.W. Scharpf and V.A. Schmidt (eds.), Welfare and Work in the Open Economy. In Vulnerability to Competitiveness (Vol. 1, pp. 21-124). Oxford: Oxford University Press.

Sundström, M. 1991. Sweden: Supporting work, family, and gender equality. See Kammerman \& Kahn 1991, pp. 171-200.

Wennemo, I. 1993. Motives and institutions in the formation of family policy: A comparative study of 18 OECD countries. Paper presented at the "Conference on comparative research on welfare states in transition, International Sociological Association, Res. Com. 19.

World Bank, World Development Indicators, ESDS International, University of Manchester. 